\title{
Some Aspects of Liver Function Status in G6PD Deficient Neonates and Its Relationship with G6PD
}

\author{
Nilufa Akhter ${ }^{1}$, Noorzahan Begum ${ }^{2}$, Sultana Ferdousi ${ }^{3}$
}

\begin{abstract}
Background: Neonatal jaundice is a common cause of newborn hospital admission. G6PD enzyme defects is one of the factor to develop neonatal hyperbilirubinemia, which may be related to abnormal liver function in this group of neonates. Objective: To observe some aspects of liver function status by measuring serum bilirubin and alanine amino transferase levels in G6PD deficient neonates and also their relationship with erythrocyte G6PD levels. Methods: The study was conducted on 30 male, term neonates with G6PD deficiency in the Department of Physiology, Bangabandhu Sheikh Mujib Medical University (BSMMU) between 1st July 2007 to 30th June 2008. For comparison age and sex matched 30 apparently healthy neonates without deficiency (control group) were also included in the study. Erythrocyte G6PD level was measured by Spectrophotometric method by using kit of Randox. Alanine amino transferase level was done by Schumann and Klauke method. For statistical analysis independent sample " $t$ " test and Pearson's correlation coefficient test were performed as applicable by using SPSS for windows version-13 Results: In this study, significantly $(\mathrm{p}<0.001)$ higher level of serum bilirubin \& ALT were found in G6PD deficient group in comparison to those of non-deficient group. Further more, serum bilirubin \& ALT levels were negatively $(\mathrm{r}=-.671,(\mathrm{r}=-.534)$ correlated with erythrocyte G6PD level and it was statistically significant $(p<0.01)$ in G6PD deficient group. Again, significant $(\mathrm{p}<0.05)$ positive $(\mathrm{r}=+.429)$ correlation of serum bilirubin level was observed in non deficient group. Whereas, non significant positive $(\mathrm{r}=+.041)$ correlations of ALT was found in non deficient group. Conclusion: From the study results it can be concluded that higher level of alanine amino transferaseand hyperbilirubinemia were present in G6PD deficient neonates \& increase serum bilirubin and serum alanine amino transferase levels were associated with degree of G6PD enzyme deficiency.
\end{abstract}

Key words: G6PD, ALT, Neonate, Hyperbilirubinemia.

J Bangladesh Soc Physiol. 2012 June; 7(1): 36-40 For Authors Affiliation, see end of text.

http://www.banglajol.info/index.php/JBSP

\section{Introduction}

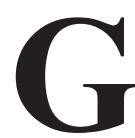

lucose-6-phosphate dehydrogenase (G6PD) is an enzyme that catalyses the first step of hexose monophosphate shunt ${ }^{1}$. Glucose-6-phosphate dehydrogenase deficiency is a genetically determined X-linked disorder, primarily affects male. The prevalence

Received: January 2012; $\quad$ Accepted: May 2012 of G6PD enzyme deficiency is high in Africa, the South East Asia, the Mediterranean the Middle East and also in population of the Indian subcontinent ${ }^{2}$. Incidence of neonatal jaundice is significantly higher in G6PD deficiency in comparison to that of non deficient neonates. Though most of the G6PD deficient subjects show no symptoms but they are vulnerable to

J Bangladesh Soc Physiol. 2012, June; 7(1): 36-40 
develop neonatal jaundice. In the last two decades, numerous studies have shown that G6PD deficiency is a potential cause of neonatal jaundice. Investigators from different countries reported that significantly higher serum bilirubin level is a usual finding in neonates with G6PD deficiency $3,4,5,6$. They also reported about different values of serum bilirubin level in erythrocyte G6PD deficient neonates, some of them found $>20 \mathrm{mg} / \mathrm{dl}^{7,11}$ in this group of neonates. Decreased conjugation and excretion of bilirubin by the liver had major contribution to the development of neonatal jaundice in G6PD deficient neonates ${ }^{6,7}$. Some investigators reported that most of this enzyme deficient neonates developed exaggerated jaundice due to deficiency of the enzyme in the liver cells. Therefore, some changes in liver function have been reported by several investigators in G6PD deficient neonates ${ }^{8,9}$. In their study, they found increase serum alanine amino transferase level due to deficiency of G6PD enzyme in liver cells. Different group of investigators found some changes in liver function in G6PD deficient neonates ${ }^{9,10}$. In addition to G6PD deficient patients, some researcher's studied serum alanine amino transferase in patients with viral hepatitis. They found non significant higher serum alanine amino transferase level in this group than that of non deficient group. After reviewing the effect of G6PD deficiency on liver function in children they reported that the decrease in serum alanine amino transferase level was associated with degree of G6PD enzyme deficiency rather than the severity of hepatitis. Though, a few study was done to observe G6PD status in adult \& children $^{13,14}$ but no data has yet been reported about the liver function status of these G6PD deficient neonates in our country. Therefore, the present study was undertaken to observe some aspects of liver function status by measuring serum bilirubin \& alanine amino transferase levels in this group of neonates and their relationship with G6PD level.

\section{Methods}

The present cross sectional study was carried out in the Department of Physiology, BSMMU,
Dhaka between July 2007 to June 2008 and the protocol was approved by the Ethical Committee of BICH \& Department of Physiology BSMMU, Dhaka. A total number of 60 male, term, neonates were included in this study. Thirty apparently healthy neonates without G6PD deficiency were considered as control and 30 neonates with G6PD deficiency were considered as study group. Control group was selected from Out Patient Department and study groups were selected from In Patient Department of Dhaka Shishu Hospital Dhaka. After selection of the subjects, aims, objectives and detail procedure of the study and the benefit of the child from the study were explained to the parents and they were encouraged for voluntary participation and written informed consents were also taken from them. The case of G6PD deficiency was diagnosed by determination of G6PD enzyme level, using kit of Randox (Spectrophotometric method). Parents were interviewed for detail history and thorough physical examinations of all the neonates were done on the 1st day of their visit/admission into the hospital. All information's were recorded in a prefixed questionnaire. Then with all aseptic precautions $2 \mathrm{ml}$ of venous blood was drawn by a disposable plastic syringe \& was transferred in a deionized plastic test tube. Then the serum was collected for estimation of bilirubin and serum alanine amino transferase (ALT) levels. Serum bilirubin level was measured by Modified Jendrassik/Grof method ${ }^{18}$. Serum ALT level was done by Schumann and Klauke method ${ }^{18}$. Data were expressed by mean $\pm \mathrm{SD}$. Data analysis was done by using SPSS windows version-13. For statistical significance, independent-sample " $\mathrm{t}$ " test was done for comparison between the groups and Pearson's correlation coefficient test was performed as the test of significance.

\section{Results}

The mean $( \pm \mathrm{SD})$ age and weight of all subjects were almost similar and they were matched for age and sex. Mean total serum bilirubin and alanine amino transferase levels were higher in G6PD deficient group in comparison to that of non deficient group and the differences of these values were statistically significant $(p<0.001)$ (Table I). 
Table I : Serum bilirubin and serum alanine amino transferase (ALT) levels in both the groups of neonates $(\mathrm{n}=60)$.

\begin{tabular}{lccc}
\hline Parameter & $\begin{array}{c}\text { G6PD non-deficient group } \\
(\mathrm{n}=30)\end{array}$ & $\begin{array}{c}\text { G6PD deficient group } \\
(\mathrm{n}=30)\end{array}$ & p value \\
\hline Bilirubin & $3.00 \pm 0.93$ & $26.42 \pm 1.66$ & $0.000^{* * *}$ \\
$(\mathrm{mg} / \mathrm{dl})$ & $(1.5-4.8)$ & $(23.80-29.6)$ & \\
ALT & $23.30 \pm 4.52$ & $44.66 \pm 4.68$ & $0.000^{* * *}$ \\
$(\mathrm{U} / \mathrm{L})$ & $(19-41)$ & $(38-56)$ & \\
\hline
\end{tabular}

Data are expressed as Mean \pm SD. For statistical analysis, independent-Sample " $t$ " test was done for comparison between the groups. Figures in parentheses indicate ranges.

G6PD non-deficient group $=$ neonates having G6PD $>245 \mathrm{mU} / 10^{9}$ erythrocyte.

G6PD deficient group $=$ neonates having G6PD level $<245 \mathrm{mU} / 10^{9}$ erythrocytes.

$* * *=\mathrm{p}<0.001 . \mathrm{n}=$ Number of subjects $\mathrm{ns}=$ Not significant.

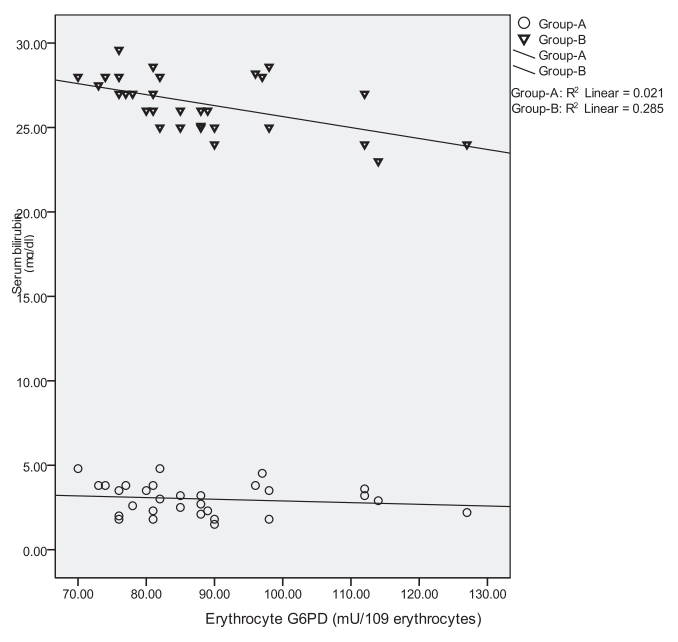

Figure 1: Correlations of serum bilirubin with erythrocyte G6PD level in both the groups of neonates $(\mathrm{n}=60)$. G6PD non-deficient group $=$ neonates having G6PD $>245 \mathrm{mU} / 10^{9}$ erythrocyte. G6PD deficient group= neonates having G6PD level $<245 \mathrm{mU} / 10^{9}$ erythrocytes.

Serum bilirubin \& serum alanine amino transferase levels were negatively $(\mathrm{r}=-.671, \mathrm{r}=-.534)$ correlated with erythrocyte G6PD levels respectively and those relationships were statistically significant $(p<0.01)$ in G6PD deficient group. Again, significant $(\mathrm{p}<0.05)$ positive $(\mathrm{r}=+.429)$ correlation of serum bilirubin level and non significant positive $(\mathrm{r}=+.041)$ correlations of alanine amino transferase levels were found in non deficient group. (Figure 1,2).

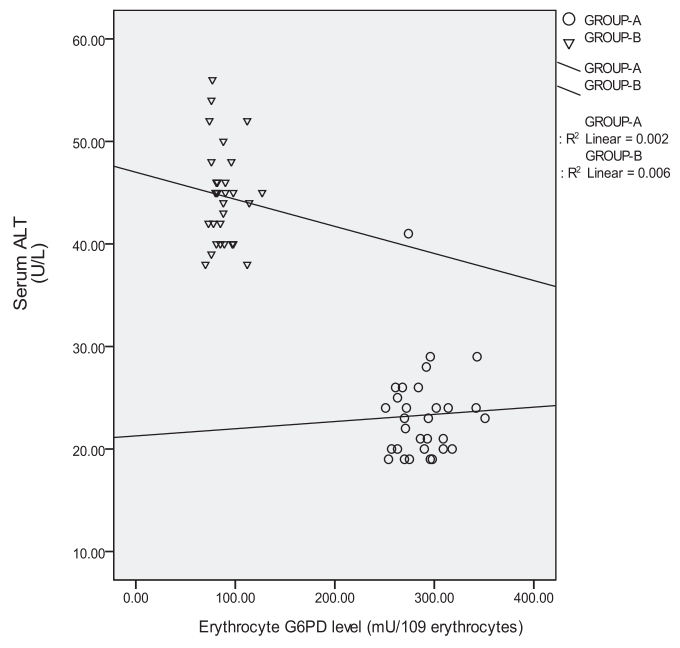

Figure 2: Correlations of serum alanine amino transferase with erythrocyte G6PD level in both the groups of neonates $(n=60)$. G6PD non-deficient group = neonates having G6PD $>245 \mathrm{mU} / 10^{9}$ erythrocyte, G6PD deficient group= neonates having G6PD level $<245 \mathrm{mU} / 10^{9}$ erythrocytes.

\section{Discussion}

In the present study serum bilirubin and serum alanine amino transferase levels were measured to evaluate some aspects of liver function status in G6PD deficient neonates and also correlations of these parameters with erythrocyte G6PD levels in order to observe any relationships among them.

J Bangladesh Soc Physiol. 2012, June; 7(1): 36-40 
In this study, higher mean serum bilirubin levels were found in G6PD deficient group of neonates $\&$ it was more than $26 \mathrm{mg} / \mathrm{dl}$. Again, significantly higher serum bilirubin and serum alanine amino transferase levels were also observed in G6PD deficient group in comparison to that of non deficient group. Almost similar findings were reported by some other investigators ${ }^{7,8}$, Furthermore, the results of the study showed significant negative association between serum bilirubin \& serum alanine amino transferase levels with erythrocyte G6PD levels, which is also similar to the findings observed by several investigators. ${ }^{9,12,15}$

Some researchers suggested that the deficiency of G6PD in the liver cells lead to decreased bilirubin conjugation due to its enzyme defect and this may be a major factor related to abnormal liver function in this group of neonates ${ }^{16,17}$. Investigators from different countries showed that additional genetic factor might exacerbate hyperbilirubinemia in G6PD deficient neonates. The genetic basis for the condition has been identified as a polymorphism in the promoter for the gene which leads to reduced enzyme activity and subsequently caused decreased bilirubin conjugation ${ }^{4,10,17 .}$

Some investigators suggested that rate limiting enzyme in the production of bilirubin was

increased in G6PD enzyme deficiency which subsequently aggravate the bilirubin level ${ }^{6,10}$.In this study, higher serum bilirubin and higher ALT levels in G6PD deficient group and their negative correlation with erythrocyte G6PD levels support liver cells enzyme defect in this group of neonates.

\section{Conclusion}

Study results concluded that higher level of alanine amino transferase and hyperbilirubinemia were occurs in G6PD deficient neonates \& their higher levels were associated with degree of G6PD enzyme deficiency.

J Bangladesh Soc Physiol. 2012, June; 7(1): 36-40

\section{Acknowledgment}

The authors of this article acknowledge all parents of the participant of this study and Dhaka Shishu Hospital for giving permission for sample collection and laboratory facility.

\section{Author Affiliations}

1. *Nilufa Akhter. Assistant Professor of Physiology, Bangladesh Institute of Child

Health, Dhaka Shishu Hospital, Dhaka, Bangladesh.

2. Professor Noorzahan Begum, Professor of Physiology, BSMMU, Shahbag, Dhaka, Bangladesh.

3. Sultana Ferdousi, Associate Professor of Physiology, BSMMU, Shahbag, Dhaka, Bangladesh.

\section{References}

1. ChanTK. Erythrocyte Glucose-6-Phosphate Dehydrogenase Deficiency. The bulletin of the Hong kong Chinese Medical Association. 1968;20: 34-44.

2. ChanTK. Glucose-6-phosphate dehydrogenase (G6PD) deficiency: A Review. HK J Paediatr(New Series) 1996; 1: 23-30.

3. BeutlerE, Glucose-6-phosphate dehydrogenase deficiency. Engl J Med. 1991; 324: 169-74.

4. Atay E, Bozaykut A, Ipek IO, Glucose-6phosphate dehydrogenase deficiency in neonatal indirect hyperbilirubinemia. $J$ Trop pediatr. 2006; 52(1): $56-58$

5. Ardhakani SB, Nikkhah A, Sedaghat M. The association between G6PD deficiency and total serum bilirubin level in icteric neonates. Acta Medica Iranica. 2007; 45(3): 233-235.

6. Abolghashemi H, Mehrani H, Amid A. An update on the prevalence of glucose-6-phosphate dehydrogenase deficiency and neonatal jaundice in Tehran neonates.Clin Biochem. 2004; 37(3): 241-4.

7. Al-Omran A, Al-Ghazal F, Gupta S, Jhon TB. Glucose-6-phosphate dehydrogenase deficiency and neonatal jaundice in Al- Hofuf area. Ann Trop Paediatr. 1998; 7(2): 98-140.

8. Gotsman I, Muszkat M. Acute viral hepatitis and glucose-6-phosphate dehydrogenase deficiency.J Gasteroenterol and Hepatol. 2001; 16: 1239- 1243.

9. Oluboyeda OA, Esan GJ, Francis TI, Luzzatto L. Genetically determined deficiency of glucose-6phosphate dehydrogenase (type-A-) is expressed in the liver. J Lab Clin Med. 1979; 93(5): 783-9. 
10. Sgro M, Campbell D, Shah V. Incidence and causes of severe neonatal hyperbilirubinemia in Canada. Can Med Assoc J. 2006; 175(6): 10-15.

11. Weng YH, Chou YH, Lien RI. Hyperbilirubinemia in healthy neonates with glucose-6-phosphate dehydrogenase deficiency. Early Hum Dev. 2003; 71(2): 129-36.

12. Carter SM, Gross SJ. Glucose-6-phosphate Dehydrogenase Deficiency. [Internate].2005 Aug 29 [cited 2007 Nov 21]. Available from: http:/ $w w w$. emedicine. Com/med/opic 900.htm

13. Sultana N, Begum N, Begum S, Ferdousi S, Ali T. Effects Of Vitamin E Supplementation On Some Aspect Of Hematological Variable In Patient Of Hemolytic Anemic Patient With Glucose-6Phosphate Dehydrogenase Deficiency. Bangladesh J of Physiol Pharmacol. 2006; 22(1/2):12-17.
14. Bedowra Z, Jebun N, N Nabi, A Baki, S Tayyeb, Kishwar A, Nazmun N. Risk factors and outcome of neonatal jaundice in a tertiary hospital.Ibrahim Med. Coll. J. 2010; 4(2): 70-73.

15. Kaplan M, Algur N, Hammerman C. Onset ofjaundice in Glucose-6-phosphate Dehydrogenase Deficient Neonates. J Am Acad Pediatr. 2001;108(4): 956-59.

16. Lai HC, Lai PYM, Leung SNK. Glucose-6Phosphate Dehydrogenase Deficiency In Chinese. J. Clin. Path. 1968; 21: 44-47.

17. Kaplan M, Hammerman C. Glucose-6-Phosphate Dehydrogenase Deficiency: A Worldwide Potential Cause of Severe Neonatal Hyperbilirubinemia.Pediatrics in Review Neo Reviews. 2000; 1: 32-39.

18. Jendrassik L, Grof P. Biochem Z. 1938; 81: 297. 17. Dacie SJV, Lewis SM. Practical Hematology. London: ELBS; 1994. 13-17p. 